\title{
Diagnosis and localization of a complicated urinary tract infection in neurogenic bladder disease by tubular proteinuria and serum prostate specific antigen
}

\author{
K Everaert ${ }^{1}$, C Oostra ${ }^{2}$, J Delanghe ${ }^{3}$, J Vande Walle ${ }^{4}$, M Van Laere ${ }^{2}$ and W Oosterlinck ${ }^{1}$ \\ ${ }^{1}$ Department of Urology, ${ }^{2}$ Department of Rehabilitation, ${ }^{3}$ Department of Clinical Chemistry and ${ }^{4}$ Department of \\ Pediatric Nephrology, University of Ghent, Belgium
}

\begin{abstract}
Introduction: Urinary tract infection is the most frequent complication occurring in patients with spinal cord injuries and can cause renal failure and male infertility. We used the urinary $\alpha-1$-microglobulin $(\alpha 1 \mathrm{Mg})$ as a marker for pyelonephritis and the serum prostate specific antigen (PSA) as a marker for prostatitis with reference to the currently available methods. The aim of our study is (1) to differentiate between upper (pyelonephritis) and lower urinary tract infection (cystitis, prostatitis) in neurogenic bladder disease, (2) to determine if high $\left(\leqslant 38.5^{\circ} \mathrm{C}\right)$ fever in a neurogenic bladder disease patient was due to urological (prostatitis, pyelonephritis) causes or not.

Patients and methods: We evaluated 147 patients of whom 27 had acute pyelonephritis, 16 had prostatitis with fever, 13 had chronic pyelonephritis, 68 had cystitis; 23 were control patients of whom nine had fever $\left(\leqslant 38.5^{\circ} \mathrm{C}\right)$ and 14 did not. The diagnoses and localizations were made on the basis of clinical evidence, with a CT scan, urography, bladder wash-out tests, and five glass-specimen tests. The urinary $\alpha 1 \mathrm{Mg}$ was determined using latex enhanced immunonephelometry and the serum PSA was measured using RIA.

Results: For the urinary $\alpha 1 \mathrm{Mg}$, the sensitivity is $96 \%$ and the specificity $93 \%$ for the diagnosis of acute pyelonephritis. The serum PSA has a sensitivity of $69 \%$ and specificity of $96 \%$ in the diagnosis of prostatitis. The urinary $\alpha 1 \mathrm{Mg}$ has a sensitivity of $96 \%$ and a specificity of $56 \%$ and the serum PSA has a sensitivity of $68 \%$ and a specificity of $100 \%$ in the differential diagnosis of prostatitis and pyelonephritis. The best discriminative parameter between pyelonephritis and prostatitis was the urinary $\alpha 1 \mathrm{Mg} / \mathrm{serum}$ PSA ratio with a sensitivity of $92 \%$ and specificity of $88 \%$.

Conclusion: Upper-tract infection with fever can be diagnosed in neurogenic bladder disease by determining the urinary $\alpha 1 \mathrm{Mg}$. In male patients, the serum PSA should be determined to distinguish upper-tract infection from prostatitis. High fever does not significantly influence our parameters so that we can differentiate whether or not high fever is due to urological causes.
\end{abstract}

Keywords: $\alpha$-1-microglobulin; urinary tract infection; prostate specific antigen; neuropathic bladder; pyelonephritis, paraplegia; spinal cord injury

\section{Introduction}

Even with modern treatment modalities, urinary tract infection (UTI) remains a frequent complication (57$62 \%$ ) after spinal cord injury. 1,2 Symptomatic infections occur in 22 to $45 \%$ of the patients. ${ }^{1,2}$ UTIs are not only a frequent pathology in this patient group but can cause severe complications such as renal damage and infertility. ${ }^{3}$ The diagnosis and/or localization of a UTI in patients with neurogenic bladder disease is often uncertain because of the lack of specific symptomatology and because several other diseases

Correspondence: K Everaert cause high fever in these patients (tissue sores, pulmonary infections, and orthopedic infections).

Localization of an upper tract infection can be achieved with a CT scan of the kidneys, an isotopic scan of the kidneys, or a bladder wash-out test. ${ }^{4-7}$ These tests are not easily accessible: they are expensive or time consuming and require transportation of the patient. CT scan and isotopic scans are considered the gold standards. ${ }^{4,5}$ The bladder wash-out test can differentiate between high and low UTI but it has never been accepted as the gold standard. This test can be false positive in prostatitis, ${ }^{7}$ which itself is difficult to diagnose. ${ }^{8}$ Digital rectal examination and ultra- 
sound are only helpful in diagnosing prostatic abscess formation. In neurogenic bladder disease, prostatitis can only be diagnosed by five glass-specimen tests or prostatic biopsy, ${ }^{8}$ neither of which can be performed during acute prostatitis because of the risk of septicemia. In neurogenic bladder disease, an accessible, quick and safe procedure is needed to diagnose and localize a UTI.

Acute pyelonephritis is an acute focal interstitial nephritis, secondary to an ascending infection, leading to tubular dysfunction at several levels (collecting tubules, proximal tubules). Acute pyelonephritis damages the proximal renal tubules, which causes leakage of tubular proteins ${ }^{9-11}$ and renal enzymes ${ }^{12,13}$ into the urine. Renal enzymes ( $\beta$-N-acetyl glucosaminidase) have not proven to be useful in the localization of a urinary tract infection in spinal cord injury patients. ${ }^{12}$ We have been unable to find any studies of tubular proteins in neurogenic bladder disease patients. Serum proteins with a molecular mass of less than $40000 \mathrm{Da}$ easily cross the glomerular membrane and are subsequently reabsorbed by the renal tubule so that only extreme low quantities are found in normal urine. Damage of the proximal tubule will result in leakage of these small proteins into the urine. Pyelonephritis is known to damage the proximal tubule and could therefore be diagnosed or followed by measuing these small proteins in urine. Any damage of the tubules (eg interstitial nephritis, heavy metal poisoning, diabetes, renal insufficiency, aminoglycosides, contrast media and chemotherapy) will lead to the appearance of these proteins in the urine. For the diagnosis of pyelonephritis we have chosen the tubular protein $\alpha$-1-microglobulin because of its stability (even at room temperature), its determination by immunonephelometry, and the accessibility of the method.

The prostate specific antigen (PSA) is a specific prostatic marker. The reference range in serum is less than $4 \mathrm{ng} / \mathrm{ml}$, and its concentration rises in prostate cancer, trauma, or infection. ${ }^{14}$ Even physical exercise, digital rectal examination, and cytoscopy may increase the serum PSA levels. ${ }^{14,15}$ Because this is an extremely sensitive parameter, traumatic catheterization and even non-traumatic intermittent catheterization can give false high PSA serum levels. The use of this parameter in the diagnosis of prostatitis does not seem to have been reported in the literature.

The aim of our study is (1) to differentiate between upper urinary tract infection (pyelonephritis) and lower urinary tract infection (cystitis, prostatitis) in neurogenic bladder disease, (2) to determine if high $\left(>38.5^{\circ} \mathrm{C}\right)$ fever in a neurogenic bladder disease patient was due to urological (prostatitis, pyelonephritis) causes or not. We used the urinary $\alpha-1$ microglobulin $(\alpha 1 \mathrm{Mg})$ as a marker for pyelonephritis and the serum prostate specific antigen (PSA) as a marker for prostatitis with reference to the currently available methods (clinical evidence, urography, CTscan, bladder wash-out test, five glass-specimen test).

\section{Patients and methods}

\section{Patients}

Between December 1994 and June 1996, we evaluated 124 patients ( $74 \%$ male, $16 \%$ female; age $30 \pm 17$ years) with a neuropathic bladder and a UTI. Our patient group was predominantly spinal cord injury patients with paraplegia $(n=58)$ or tetraplegia $(n=30)$, meningomyeloceles $(n=16)$, or other neurological diseases $(n=20)$. Exclusion criteria were renal insufficiency, diabetes, nephrotoxic medication (aminoglucocides, chemotheraphy), prostatic hypertrophy, prostatic cancer or traumatic catheterization (within 2 weeks). We also evaluated 16 patients with clam-bladder augementation with an asymptomatic urinary-tract infection.

The localization of the UTI was done clinically in 26 patients with partial or complete preservation of pain sensation (acute pyelonephritis: $n=6$, acute prostatitis: $n=3$, cystitis: $n=15$ ). The bladder washout test alone or in combination with five glassspecimen tests was used in 77 patients (acute pyelonephritis: $n=15$, prostatitis: $n=12$, cystitis: $n=50)$. Intravenous urography was used in nine patients (chronic pyelonephritis: $n=9$ ) and CT scan of the kidneys (diagnosis of acute pyelonephritis) in 11 patients (acute pyelonephritis: $n=6$, acute prostatitis: $n=2$, cystitis: $n=3$ ). In 1 patient, the diagnosis of prostatic abscess formation was made with a transrectal ultrasonography.

\section{Control population}

The control population consisted of 14 healthy patients with a neuropathic bladder. They had no urinary tract infection. They were mainly spinal cord injured patients $(n=12)$, and two had meningomyelocele (nine males, five females; age $28 \pm 13$ years).

We also evaluated nine patients, (five males, four females; $31 \pm 12$ years) with neurogenic bladder disease (eight had a spinal cord injury and one had a meningomyelocele) and high fever $\left(>38.5^{\circ} \mathrm{C}\right)$ due to influenza $(n=2)$, pneumonia $(n=5)$, or resorption of huge hematoma $(n=2)$. None of them had a UTI.

The control population for the serum PSA study were 26 male patients $(31 \pm 16$ years $)$ with a neurogenic bladder suffering from cystitis.

\section{Methods}

The diagnosis of UTI was accepted if more than 100000 CFU (Kass, 1956) were found with significant pyuria ( $>5$ white blood cells).

The clinical diagnosis of acute cystitis was only made in patients known to have sterile urine in the foregoing period and who developed acute symptoms of strangury, urgency, or incontinence in association with the diagnosis of UTI. The clinical diagnosis of chronic cystitis was made in patients with a chronic UTI who had had no episodes of fever for the last 
year and who had no urological symptoms. The clinical diagnosis of acute pyelonephritis was made if UTI was associated with high fever $\left(>38.5^{\circ} \mathrm{C}\right)$ and flank pain comparable with a renal colic. Acute prostatitis was diagnosed clinically if the patient complained of dysuria, urgency, perineal pain and urethral discharge.

Chronic pyelonephritis was diagnosed by intravenous urography when typical lesions such renal scarring and dilatation were seen. Acute pyelonephritis was diagnosed with a CT scan using contrast media. Typical lesions (renal abscess, wedge-shaped zones of increased and decreased enhancement, illdefined zones of low attenuation, enlarged kidney with or without decreased parenchymal enchancement) as described by Soulen et $a l^{4}$ were used. Both tests are considered gold standards for this purpose. ${ }^{5}$

A UTI can be localized in neurogenic bladder disease using the wash-out test ${ }^{7}$ in females and in combination with five glass-specimen tests in males. ${ }^{8}$ The techniques were described by Wyndaele et $a l^{7,8}$ and have been used in our department since 1979. These tests cannot be considered the gold standard as their sensitivity and aspecificity are unknown. However, no other diagnostic tools exist to diagnose prostatitis in neurogenic bladder disease. Five glassspecimen tests cannot be performed during acute prostatitis due to the high risk of septicemia. Therefore, patients known with chronic prostatitis who have a high fever $\left(>38.5^{\circ} \mathrm{C}\right)$ together with increasing pyuria and bacteruria were considered as having acute prostatitis. In doubtful cases $(n=2)$ (reflux, stone disease, former upper tract infections), a CT scan was performed to demonstrate the absence of acute pyelonephritis.

The urinary $\alpha$-1-microglobulin was detected by latex-enhanced nephelometry (Behringwerke, Marburg, Germany). Reference values are $0-8 \mathrm{mg} /$ liter. The concentration of the urinary $\alpha 1 \mathrm{Mg}$ was also expressed as the urinary $\alpha 1 \mathrm{Mg} /$ creatinine ratio. The serum PSA was detected with a radio immunoassay (Tandem-R PSA Hybritech Europe SA, Liège, Belgium). The cut-off value was $4 \mathrm{ng} / \mathrm{ml}$.

We compared the urinary $\alpha 1 \mathrm{Mg}$ and the serum PSA of patients with cystitis to the urinary $\alpha 1 \mathrm{Mg}$ and the serum PSA in patients with acute pyelonephritis, chronic pyelonephritis, and prostatitis with fever. The control population was used to prove that high fever and cystitis do not cause an increase of the urinary $\alpha 1 \mathrm{Mg}$. We also looked to the value of the urinary $\alpha 1 \mathrm{Mg}$ in patients with an intestinal segment in the urinary tract and the influence on intermitent catheterization on the serum PSA.

Data are given as median (lower quartile-upper quartile). Comparison between groups was done with the Wilcoxon test. Analysis of sensitivity and specificity was performed using the receiver operator curve (ROC). All individual results and medians with lower and upper quartiles for the subpopulations are given in Figure 1.

\section{Results}

Urinary $\alpha 1 \mathrm{Mg}$ in the control population, in patients with high fever but without UTI and in patients with cystitis In the control population $(n=14)$, the urinary $\alpha 1 \mathrm{Mg}$ concentration was $5 \mathrm{mg} / 1(5-5 \mathrm{mg} / \mathrm{l})$ and the urinary $\alpha 1 \mathrm{Mg} /$ creatine ratio was $0.012(0.007-0.018)$. In the nine patients with high fever $\left(>38.5^{\circ} \mathrm{C}\right)$ and without a UTI we found a urinary $\alpha 1 \mathrm{Mg}$ concentration of $5 \mathrm{mg} / 1$ $(5-9 \mathrm{mg} / \mathrm{l})$ and a urinary $\alpha 1 \mathrm{Mg} /$ creatinine ratio of $0.007(0.005-0.011)$. Table 1 shows that there were no differences in this respect between these two groups. Results are depicted in Figure 1.

Table 1 gives the results of the urinary $\alpha 1 \mathrm{Mg}$ excretion $(6 \mathrm{mg} / 1(5-10 \mathrm{mg} / 1))$ and the urinary $\alpha 1 \mathrm{Mg} /$ creatinine ratio $(0.01(0.005-0.02))$ in the cystitis group $(n=52)$. No significant difference could be found between the control population and the cystitis group. Results are also depicted in Figure 1.

Urinary $\alpha 1 \mathrm{Mg}$ in acute pyelonephritis or in exacerbation of chronic pyelonephritis

In these patients $(n=27)$, there was a significant increase of the urinary $\alpha 1 \mathrm{Mg}$ concentration $(20 \mathrm{mg} / \mathrm{l}$ $(16-28 \mathrm{mg} / \mathrm{l}))$ and the urinary $\alpha 1 \mathrm{Mg} /$ creatinine ratio $(0.031(0.019-0.056))$. The results are listed in Table 2

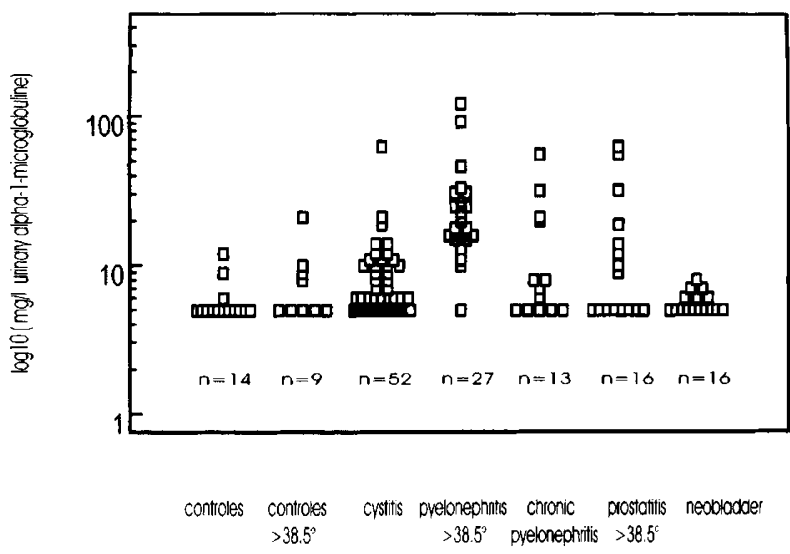

Figure 1 Urinary alpha-1-microglobuline concentrations in 147 patients with neurogenic bladder disease

Table 1 Results of the urinary $\alpha 1 \mathrm{Mg}$ and the urinary $\alpha 1 \mathrm{Mg}$ / creatinine in the control population and in cystitis

\begin{tabular}{|c|c|c|c|}
\hline & $\mathrm{n}$ & $\begin{array}{c}\alpha 1 \mathrm{Mg} \\
\mathrm{mg} . / \text { liter }\end{array}$ & $\begin{array}{l}\alpha 1 M g / \text { creatinine } \\
\text { ratio }\end{array}$ \\
\hline Control population & 14 & $5(5-5)$ & $0.012(0.007-0.018)$ \\
\hline No UTI, $>38.5^{\circ} \mathrm{C}$ & 9 & $5(5-9)$ & $0.007(0.005-0.011)$ \\
\hline Cystitis & 52 & $5(5-10)$ & $0.010(0.005-0.020)$ \\
\hline $\begin{array}{l}\text { Cystitis, Clam bladder } \\
\text { augmentation }\end{array}$ & 16 & $5(5-6)$ & $0.015(0.009-0.019)$ \\
\hline
\end{tabular}

*Values are given as median (lower quartile-upper quartile) 
Table 2 Results of the urinary $\alpha 1 \mathrm{Mg}$ concentration and the urinary $\alpha 1 \mathrm{Mg} /$ creatinine ratio in cystitis, in acute and chronic pyelonephritis and in prostatitis with fever

\begin{tabular}{|c|c|c|c|}
\hline & $\mathrm{n}$ & $\begin{array}{c}\alpha 1 \mathrm{Mg} \\
m g . / \text { liter }\end{array}$ & $\begin{array}{c}\alpha 1 \mathrm{Mg} / \text { creatinine } \\
\text { ratio }\end{array}$ \\
\hline Cystitis & 52 & $6(5-10)^{*}$ & $0.010(0.005-0.020)$ \\
\hline $\begin{array}{l}\text { Pylonephritis, } \\
\text { high fever }\end{array}$ & 27 & $20(16-28)^{* *}$ & $0.031(0.019-0.056)^{* *}$ \\
\hline $\begin{array}{l}\text { Prostatitis, } \\
\text { high fever }\end{array}$ & 16 & $7(5-15.3)$ & $0.012(0.007-0.024)$ \\
\hline $\begin{array}{l}\text { Chronic } \\
\text { pyelonephritis }\end{array}$ & 13 & $7(5-20)$ & $0.016(0.008-0.033)$ \\
\hline
\end{tabular}

*Values given as median (lower quartile-upper quartile);

$* * P=0.0005$ (Wilcoxon) versus cystitis

and shown in Figure 1. Of these 27 patients, 24 had a proven acute pyelonephritis and three had an exacerbation of their chronic pyelonephritis with high fever $\left(>38.5^{\circ} \mathrm{C}\right)$

The receiver operator curve was made for the results of the urinary $\alpha 1 \mathrm{Mg}$ concentration in patients with pyelonephritis versus patients with cystitis (sensitivity $96 \%$, specificity $73 \%$ ) and versus the control population (sensitivity 96\%, specificity 93\%) (Table 2 ).

In six patients, we followed the urinary $\alpha 1 \mathrm{Mg}$ levels until normalization. After 2 to 3 days, the urinary $\alpha 1 \mathrm{Mg}$ levels tend to normalize and 5 days later all urine samples were within reference limits.

Urinary $\alpha 1 \mathrm{Mg}$ in patients with chronic pyelonephritis, prostatitis with fever and in patients after a clam bladder augmentation

Table 2 gives the results of patients with chronic pyelonephritis $(n=13: 7 \mathrm{mg} / \mathrm{l} \quad(5-20 \mathrm{mg} / \mathrm{l}))$ and prostatitis with fever $(n=16: 7 \mathrm{mg} / 1 \quad(5-15.3 \mathrm{mg} / \mathrm{l}))$. Table 1 lists the patients with cystitis and a clam bladder $(n=16: 5 \mathrm{mg} / \mathrm{l}(5-6 \mathrm{mg} / \mathrm{l}))$ versus patients with cystitis without an augmented bladder $(n=52$ : $6 \mathrm{mg} / \mathrm{l}(5-10 \mathrm{mg} / \mathrm{l}))$. There was no statistical significant difference of the urinary $\alpha 1 \mathrm{Mg}$ concentration and the urinary $\alpha 1 \mathrm{Mg} /$ creatinine ratio between these groups relative to the cystitis group. Results are depicted in Figure 1.

\section{Serum PSA in prostatitis, acute pyelonephritis and cystitis}

A significant $(P<0.01)$ increase in serum PSA was found in the prostatitis group (11.5 ng/dl (6.75$24 \mathrm{ng} / \mathrm{dl}))$ versus the cystitis group (1.39 $\mathrm{ng} / \mathrm{dl}(0.55-$ $2.32 \mathrm{ng} / \mathrm{dl})$ ). For the serum PSA, we found a sensitivity of $69 \%$ and specificity of $96 \%$ in the differential diagnosis between prostatitis and cystitis.

No significant elevated serum PSA was found in the pyelonephritis group $(1.35 \mathrm{ng} / \mathrm{dl}(0.93-1.81 \mathrm{ng} / \mathrm{dl}))$.

From the 26 patients with cystitis, 16 performed intermittent catheterization $(\mathrm{PSA}=1.46 \mathrm{ng} / \mathrm{dl}(1.08-$ $1.82 \mathrm{ng} / \mathrm{dl})$ ) and $10 \mathrm{used}$ straining or suprapubic catheterization to empty their bladders (PSA = $0.58 \mathrm{ng} / \mathrm{dl}(0.49-2.32 \mathrm{ng} / \mathrm{dl}))$. No significant difference in serum PSA between these groups was found.

The urinary $\alpha 1 M g$ and the serum PSA in the differential diagnosis of pyelonephritis and prostatitis

In the differential diagnosis between prostatitis and pyelonephritis we found a sensitivity of $96 \%$ and a specificity of $56 \%$ for the urinary $\alpha 1 \mathrm{Mg}$ concentration (cut-off value $8 \mathrm{mg} / \mathrm{l}$ ) and a sensitivity of $68 \%$ and specificity off $100 \%$ for the serum PSA (cut-off value $4 \mathrm{ng} / \mathrm{ml}$ ). The best discriminative parameter we found between acute pyelonephritis and prostatatis is the urinary $\alpha 1 \mathrm{Mg}$ per serum PSA ratio. Plotting these $\alpha 1 \mathrm{Mg} / \mathrm{PSA}$ ratios in the receiver operator curve gives a sensitivity of $92 \%$ and specificity of $88 \%$ with a cut-off value of $5000 \mathrm{mg} / \mathrm{l}$.

\section{Discussion}

In the literature, tubular proteinuria and urinary enzymuria have been reported to be sensitive and specific markers for tubular damage. ${ }^{9-11,13}$ Using urinary enzymes have not been found to be useful in the diagnosis of upper tract infection in spinal cord injury patients. ${ }^{12}$ In our patient group with neurogenic bladder disease, we found the urinary $\alpha 1 \mathrm{Mg}$ to be a highly sensitive (96\%) and specific (93\%) marker of upper tract infection. Positive results can also be generated by other causes of tubular damage d-11,13 $^{9-1}$ like renal failure, diabetes, nephrotoxic drugs (aminoglycosides, chemotherapy, contrast media), heavy metal intoxication, myeloproliferative diseases, and AIDS. The effect of concentration or dilution of urine can theoretically be minimized when using the urinary $\alpha 1 \mathrm{Mg} /$ creatinine ratio but reduced the sensitivity and specificity in our series. Proteinuria (glomerular and tubular proteins) increases during fever, which is not just due to the urine concentration. ${ }^{9}$ The urinary $\alpha 1 \mathrm{Mg}$ has been proven to be the marker that is the least influenced by fever. ${ }^{9}$ This observation was confirmed by our data (control group with fever and without UTI). Finally, the dosage of $\alpha 1 \mathrm{Mg}$ was not influenced by the variability of urinary composition and remains stable at room temperature for a long time. For all these reasons we found the urinary $\alpha 1 \mathrm{Mg}$ to be a very practical and reliable marker of acute pyelonephritis.

The bladder wash-out test and the five glassspecimen tests cannot be considered gold standards. ${ }^{7,8}$ Their specificity and sensitivity is unknown, which is reflected in our results. In the differential diagnosis between prostatatis and cystitis, the serum PSA has a rather low sensitivity $(69 \%)$ and a high specificity of $96 \%$ (Table 3 ). As no accurate tool exists for the diagnosis of acute prostatitis in neurogenic bladder disease, ${ }^{8}$ a certain percentage of misdiagnoses will occur. As the serum PSA is known to be an extremely sensitive parameter (digital rectal examination, physical exercise, and cystoscopy increases the 
Table 3 Results of the receiver operator curves for pyelonephritis (urinary $\alpha 1 \mathrm{Mg}$ and $\alpha 1 \mathrm{Mg} / \mathrm{creatinine}$ ratio) and prostatitis (serum PSA)

\begin{tabular}{|c|c|c|c|c|}
\hline & \multicolumn{4}{|c|}{$R O C$} \\
\hline & Marker & Sensitivity & Specificity & Cut-off value \\
\hline \multirow[t]{2}{*}{ Acute pyelonephritis vs Control population } & $\alpha 1 \mathrm{Mg}$ & $96 \%$ & $93 \%$ & $8 \mathrm{mg} / 1$ \\
\hline & $\alpha 1 \mathrm{Mg} /$. creat. & $82 \%$ & $71 \%$ & 0.017 \\
\hline \multirow{2}{*}{ Acute pyelonephritis vs Cystitis } & $\alpha 1 \mathrm{Mg}$ & $96 \%$ & $73 \%$ & $8 \mathrm{mg} / 1$ \\
\hline & $\alpha 1 \mathrm{Mg} /$ creat. & $82 \%$ & $71 \%$ & 0.017 \\
\hline Prostatitis vs Cystitis & serum PSA & $69 \%$ & $96 \%$ & $4 \mathrm{ng} / \mathrm{ml}$ \\
\hline \multirow[t]{3}{*}{ Acute pylonephritis vs Prostatitis } & $\alpha 1 \mathrm{Mg}$ & $96 \%$ & $56 \%$ & $8 \mathrm{mg} / 1$ \\
\hline & serum PSA & $68 \%$ & $100 \%$ & $4 \mathrm{ng} / \mathrm{ml}$ \\
\hline & $\alpha 1 \mathrm{Mg} / \mathrm{PSA}$ & $92 \%$ & $88 \%$ & 5000 \\
\hline
\end{tabular}

serum PSA), ${ }^{14,15}$ its sensitivity for the diagnosis 'prostatitis', must be higher than $69 \%$.

In the differential diagnosis between pyelonephritis and prostatitis, the serum PSA had high specificity $(100 \%)$ and low sensitivity $(68 \%)$. In the pyelonephritis group, no patient had a serum PSA above $4 \mathrm{ng} / \mathrm{ml}$. In the prostatitis group 5/16 patients had a normal serum PSA. This can be explained by the rather low sensitivity and specificity of the diagnosis 'prostatitis' by all other means used. ${ }^{7,8}$ The sensitivity of the urinary $\alpha 1 \mathrm{Mg}$ in the differential diagnosis between pyelonephritis and prostatitis was $96 \%$ and the specificity was $56 \%$. Although pyelonephritis was excluded, 3/16 patients with prostatitis and high urinary $\alpha 1 \mathrm{Mg}$ concentrations were found. All three patients had a high fever $\left(39.5^{\circ}\right.$ to $\left.40^{\circ} \mathrm{C}\right)$ and had been ill for several days while the other patients were seen at the onset of the disease. Therefore, in male patients with a UTI and fever, one should always determine, both urinary $\alpha 1 \mathrm{Mg}$ and the serum PSA. If a male patient has a urinary $\alpha 1 \mathrm{Mg}$ above $8 \mathrm{mg} / 1$ and a serum PSA $<4 \mathrm{ng} / \mathrm{ml}$, we diagnose pyelonephritis. If both the urinary $\alpha 1 \mathrm{Mg}$ and serum PSA are elevated we can diagnose prostatitis but a concomitant pyelonephritis is not excluded.

Most of our patients perform intermittent catheterization to achieve continence as much as possible. Therefore, the influence of intermittent catheterization on the serum PSA is an important factor. Indeed, digital rectal examination or cystoscopy increase the serum PSA. ${ }^{14}$ Even physical exercise (bicycle ergometer) can cause a threefold increase of serum PSA, which is likely due to squeezing of the prostate gland. ${ }^{15}$ Intermittent catheterization did not influence the serum PSA in our series. The median serum PSA concentration was slightly higher in the group that performs intermittent catheterization but this was not statistically significant and the upper quartile $(1.81 \mathrm{ng} /$ $\mathrm{ml}$ ) was largely below $4 \mathrm{ng} / \mathrm{ml}$. Traumatic catheterization could cause an important increase of the serum PSA as does cystoscopy, so these patients were ruled out of the study.

With increasing age, a higher incidence of prostatic hypertrophy and of prostate cancer is seen. Both pathologies are responsible for elevated serum PSA
Table 4 Results of the serum PSA in patients with cystitis, prostatitis with fever, and acute pyelonephritis

\begin{tabular}{lcc}
\hline & $\mathrm{n}$ & Serum PSA, ng/dl \\
\hline Cystitis all patients & 26 & $1.39(0.55-2.32)^{*}$ \\
$\begin{array}{l}\text { Cystitis + intermittent } \\
\quad \text { catherterization }\end{array}$ & 16 & $1.46(1.07-1.82)$ \\
$\begin{array}{l}\text { Cystitis + other means of } \\
\quad \text { bladder emptying }\end{array}$ & 10 & $0.58(0.49-2.32)$ \\
$\begin{array}{l}\text { Prostatitis with fever } \\
\text { Acute pyelonephritis }\end{array}$ & 16 & $10.05(3.56-10.93)^{* *}$ \\
\hline
\end{tabular}

*Values are given as median (lower quartile-upper quartile); ** $P=0.0001$ versus cystitis

values. ${ }^{14}$ Above 45 years of age one should always rule out a prostatic hypertrophy or a cancer as a cause of PSA elevation (above $4 \mathrm{ng} / \mathrm{ml}$ ). As prostate volume increases with age, the PSA will increase with age too and therefore, a serum PSA of $6 \mathrm{ng} / \mathrm{ml}$ will be of less diagnostic value of prostatitis at the age of 50 than at the age of 20. As our population (predominance of spinal cord injury patients and meningomyeloceles) is relatively young $(30 \pm 17$ years $)$, the age-related PSA elevation did not influence our results.

The diagnosis and localization of a UTI in a neurogenic bladder disease patient with urinary $\alpha 1 \mathrm{Mg}$ and serum PSA have the advantages that no transportation of the patient is necessary, that the method is readily accessible and cheaper (also in combination with the PSA), and that no contrast media, tracers, or X-rays are needed. After starting antibiotics, the urinary $\alpha 1 \mathrm{Mg}$ stays high for up to 5 days whereas the serum PSA stays high for 2 weeks or more. ${ }^{14}$ This means that even if empiric antibiotics were started before a urine culture and sediment were taken (which normalize within $24 \mathrm{~h}$ after the onset of antibiotics), a post hoc diagnosis of pyelonephritis or prostatitis can be made.

\section{Conclusion}

The urinary $\alpha 1 \mathrm{Mg}$ is a highly specific and sensitive marker for pyelonephritis. The urinary $\alpha 1 \mathrm{Mg}$ can distinguish if fever is from urological causes or not. In man a serum PSA must be taken. The serum PSA is 
a specific diagnostic tool to distinguish prostatitis from pyelonephritis or other febrile diseases. Both markers are non-invasive and more readily accessible relative to the current diagnostic tests. Even after empirically started antibiotics, when urine sediment and culture are normal, the diagnosis of pyelonephritis and prostatitis is possible.

\section{Acknowledgements}

The authors wish to thank the Goethem Brichand foundation for its donation and Behring Werke (Marburg, Germany) for providing the necessary reagents.

\section{References}

1 Waites KB, Canupp KC, De Vivo MJ. Epidemiology and risk factors for urinary tract infection, following spinal cord injury. Arch Phys Med Rehabil 1993; 74/7: 691-695.

2 Van Kerrebroeck PEV et al. The morbidity due to lower urinary tract function in spinal cord injury patients. Paraplegia 1993; 31 $320-329$.

3 Barton CH, Vaziri ND, Gordon S, Telles S. Renal pathology in end stage renal disease associated with paraplegia. Paraplegia 1984; 22: $31-41$.

4 Soulen MS. Bacterial renal infection. Radiology 1989; 171: $703-$ 707.

5 Talner L et al. Acute pyelonephritis: can we agree on terminology? Radiology 1994; 192: 297-305.
6 Wyndaele JJ, Everaert K, Rysselaere M, De Sy W. An evaluation of the bladder wash out test and the antibody coated bacteria test for the localization of a urinary tract infection in patients with and without a neurogenic bladder. Acta Urol Belg 1986; 54: 471 476.

7 Wyndaele JJ, Oosterlinck W, De Sy WA. The use of the bladder wash out test in patients with spinal cord lesions who have urinary tract infection. Paraplegia 1983; 21: 294-300.

8 Wyndaele JJ. Chronic prostatitis in spinal cord injury patients. Paraplegia 1985; 23: $164-169$

9 Donaldson MD, Chambers RE, Woolridge MW, Whicher JT. Alpha 1-microglobulin, beta 2-microglobulin and retinol binding protein in childhood hebrile illness and renal disease. Pediatr Nephrol 1990; 4/4: 314-318.

10 Gruev I et al. Beta 2-microglobulin in chronic exacerbated pyelonephritis. Vutr-Boles 1988; 27/4: 44-46.

11 Pupek-Musialik D. Usefulness of beta-2-microglobulin determination in the differential diagnosis of infection in the upper and lower parts of the urinary tract. Wiad-Lek 1990; 43/5-6: $183-$ 187.

12 Uozumi $\mathrm{J}$ et al. Urinary $\mathrm{N}$-acetyl-beta-D-glucosaminidase activity in acute pyelonephritis patients with spinal cord injuries. Nippon Hinoyokika Gakkai Zasshi 1989; 80/1: 54-58.

13 Dunjic R, Ivanovic I, Stojanov M. Changes in N-acetyl-betal-Dglucosaminidase in the urine of patients with pyelonephritis and glomerulonephritis. Vojnosanit Pregl 1991; 48/2: 136-138.

14 Stamey TA, McNeal JE. Adenocarcinoma of the prostate. In: Walsh P, Retik A, Stamey T, Vaughan E. Campbell's Urology, 6th ed. Saunders: Philadelphia 1992, pp. 1192-1193.

15 Ozemek CM, Seiffert UB. Physical activity releases prostatespecific antigen (PSA) from the prostate gland into blood and increases serum PSA concentration. Clinical Chemistry 1996; 42/5: $691-695$ 